\title{
Does government funding complement or substitute private research funding to universities?
}

\author{
Alessandro Muscio ${ }^{\mathrm{a}, *}$, Davide Quaglione ${ }^{\mathrm{b}, 1}$, Giovanna Vallanti $^{\mathrm{c}, 2}$ \\ a Dipartimento Di Scienze Economiche, Matematiche e Statistiche (DSEMS), Università degli Studi di Foggia, Largo Papa Giovanni Paolo II, 1, 71100 Foggia, Italy \\ b Dipartimento di Economia, Università “G. d'Annunzio" di Chieti e Pescara, v.le Pindaro, 42, 65127 Pescara, Italy \\ c Dipartimento di Scienze Economiche e Aziendali (DPTEA), Università Luiss Guido Carli, Viale Romania, 32, 00197 Roma, Italy
}

\section{A R T I C L E I N F O}

\section{Article history:}

Received 9 November 2010

Received in revised form 24 March 2012

Accepted 23 April 2012

Available online $\mathrm{xxx}$

\section{JEL classification:}

L24

L31

032

033

Keywords:

University

Collaboration

Technology and knowledge transfer

Research funding

Third mission

\begin{abstract}
A B S T R A C T
There is growing political pressure on universities to intensify their interaction with industry and to enlarge their own research funding options, in a context characterised by increasing constraints on public spending. However, whether the successful achievement of such a political desired outcome is consistent with a restriction of government funding is not clear and requires further investigation. As a matter of fact, there is scant empirical evidence on whether and to what extent government funding affects the external funding options available to universities, in particular those related to research and consulting activities. By using a set of probit and tobit panel data models estimated on financial data for the whole population of Italian university departments engaged in research in the Engineering and Physical Sciences, this paper provides evidence that government funding to universities complements funding from research contracts and consulting, contributing to increasing universities' collaboration with industry and activating knowledge transfer processes.
\end{abstract}

(c) 2012 Published by Elsevier B.V.

\section{Introduction}

There is increasing awareness in industrialised countries of the importance of scientific research in creating the foundations for technological change and economic competitiveness. Historically, bringing research results to market has not been of prime concern to academic institutions. However, since the late 1970s, a growing pressure has been put on universities to produce research that is valuable for industry ${ }^{3}$ and to establish closer linkages

\footnotetext{
* Corresponding author. Tel.: +390881 753730; fax: +390881 775616.

E-mail addresses: al.muscio@unifg.it (A. Muscio) d.quaglione@unich.it (D. Quaglione), gvallanti@luiss.it (G. Vallanti).

1 Tel.: +39085 4537610; fax: +39085 4537565 .

2 Tel.: +3906 85225910; fax: +390685225949.

3 Although the literature on these issues make systematic reference to "industry" (which evokes private manufacturing firms) as the typical recipient of the university knowledge transfer, third stream activities are beneficial also to private firms operating in the tertiary sector as well as to public institutions involved with the supply and deliver of (market and non-market) goods and services. In the view expressed in this paper, "industry", "businesses" and "university-industry collaboration" are interpreted in a wider sense, which emphasises a stronger market orientation of university research.
}

with the business community in order to widen the chances of establishing collaborations. Early research has typically focused on technology transfer issues such as patenting, licensing and spin-offs. More recently, greater attention has been paid to other university-industry collaboration channels such as research contracts and consulting activity, characterised by a higher degree of relational linkages, capable of generating strong learning by interaction effects (Perkmann and Walsh, 2009).

At the same time, the creation of new channels of university-industry collaboration has gained strategic relevance to universities primarily because of their potential as sources of external funding (Cohen et al., 1998). There is now substantial agreement in the economic literature that university-industry collaboration should be promoted and that governments should put in place all the necessary measures to ease this process, thereby helping to bring the results of academic research to market. Several empirical works, even very recent (Gulbrandsen et al., 2011), have investigated the drivers of university-industry collaborations and business funding to universities. However, a key factor, and one that may have been overlooked, is the existing relationship between government funding and the funding raised by universities through research contracts, consulting and, more generally, 
scientific activities to order. ${ }^{4}$ There is extensive evidence on the effects of funding on the production of innovations and on the development of university-industry networks. However, further investigation is needed in order to assess whether government funding to universities complements or substitutes funding from these other channels of collaborative interaction.

According to a recent OECD review on university funding (OECD, 2010), European universities are primarily funded by the state. The review estimates that in the large majority of cases the funding proportion lies between $60 \%$ and $90 \%$ of the total budget. However, during the last two decades, the shortcomings of the traditional 'input-orientated' funding system with respect to performancebased management systems of public administrations pushed several European governments to implement numerous reforms of research of university systems (McNab and Melese, 2003). Many developed economies have gradually reduced government funding to research systems. In Italy as well as in the USA, Japan, Germany, France, Canada, and the UK, government intervention has been reduced, thus favouring the action of market forces, which have become more and more important in allocating resources (Steil et al., 2002).

Funding systems and especially resource allocation mechanisms for public funds are an essential element of reforms of university systems in several countries. Despite an international trend towards performance-based funding, the approaches that have been implemented differ significantly across countries. According to the classification of university funding systems presented by Salmi and Hauptman (2006), Italy has a fundamentally traditional funding system similar to that of many other countries in Europe (Strehl et al., 2007): the largest part of university budgets is based on 'negotiated budgets' and 'funding formulas' (based on size of staff or number of students enrolled), but universities also compete for research funding on the basis of peer-reviewed project proposals against a set of objectives. Like in many other European countries, other sources of university funding such as industry funding is becoming increasingly important for Italian universities' budgets.

In the light of these arguments, the purpose of this paper is to investigate the effects that government funding for academic research activity has on the external funding to universities raised through research contracts and consultancies. The rationale of our empirical exercise is straightforward in terms of policy implications: we are interested in investigating whether the financial pressure that universities have been subjected to in recent years - that in the specific case of Italy has been amply reported by the media (Gandolfi, 2009; Intravaia, 2011; Magrini, 2011; Tucci, 2010) - is driving these academic institutions to look for alternative sources of funding, stimulating university-industry interactions and collaborations (substitution effect), or, conversely, it is hampering their capability to collect external funding (complementarity effect) and to activate important knowledge transfer channels.

Our research differs from previous studies in several respects. We carry out an econometric analysis based on highly disaggregated data on university departments; we discriminate between different sources of public funding ranging from EU funding to national and regional sources; we use disaggregated data on private

\footnotetext{
4 In this paper the terms "industry", "business", "private" and "market" funding must be understood as synonymous locutions referring to funding that universities raise from scientific activities to order - i.e. the research activities, consultancies and services sold on the market, carried on in response to an exclusive interest of the commissioning entity independently from its public or private legal nature which can be regarded as an effective proxy of collaborations capable of activating knowledge transfer processes based on high relationality. By contrast, "government funding" (or "public funding") is related to European Commission, national or local governments funding for research programs on topics defined as of public interest.
}

funding, testing our hypothesis concerning the nature of the relationship between public research funding and research contracts and consulting activity (thus excluding other sources of private funding to universities not related to knowledge transfer processes, such as donations).

The paper is organised as follows. Section 2 sets the theoretical background to university funding and university-industry interactions. Section 3 presents our empirical results for the determinants of industry funding to universities. Section 4 discusses the results and their implications for policy.

\section{Theoretical background}

\subsection{University funding and university-industry interaction}

Knowledge is considered to be a primary resource for wealth creation and economic growth (Drucker, 1993; Nonaka and Takeuchi, 1995; Florida, 1995; Romer, 1993, 1995; Leonard-Barton, 1995) and intellectual capital a crucial resource of economic advantage in the knowledge economy (Stewart, 1997; Edvinsson and Malone, 1997). The role of the university as an economic and social institution has become increasingly important (Florida and Cohen, 1999). Universities have long been involved in so-called 'thirdstream' activities (Geuna and Muscio, 2009), and there is evidence that they have significantly contributed to economic development and firm competitiveness. However, a deeper connection between university and industry is being seen as essential, and this requires a structural change in the role of universities within the national innovation system as well as a modernisation of their managerial and organisational skills (European Commission, 2009). The expectation is that universities not only produce new knowledge, but that this knowledge be related to established social and economic targets (Laredo, 2007). In this view, universities should (a) intensify their involvement in the economic and social development; (b) increase the commercialisation of research results, patenting and licensing activities; (c) institutionalise spin off activities; (d) introduce managerial and attitudinal changes among academics with respect to collaborative projects with industry (Van Looy et al., 2004).

Since the 1980s, many policy makers have been pushing for this 'second revolution' in academia, above all having in mind the possible enlargement of external funding options for universities and the consequent relief for government budget. Now, while some countries are in the process of rethinking the role (and funding) of research institutions within their national innovation systems (Arnold et al., 2006), several European country governments are applying increasing pressure for universities to raise research funding from industry and to contribute actively to industrial innovation. As Geuna (1999) notes, since the early 1980s European governments have been intervening more directly in terms of guiding national research systems. This intervention has taken different forms in different countries, but is being driven by similar overall targets, which are promoting a contractualoriented approach to university research funding, aimed at indirect control of the behaviour of universities through the introduction of (quasi-market) financial incentive schemes. These policies are meant to improve the efficiency of research funds and increase the accountability of universities as well as the pressure to reduce their costs, this latter objective being crucial as a consequence of the constraints on public budgets resulting from the enforcement of the Maastricht criteria (Sörlin, 2007). Confirming this, Auranen and Nieminen (2010) compare the funding environments of university research in eight countries, investigating whether more competitive funding schemes result in a more efficient production of scientific publication. The authors find that the idea of output 
and competition-based incentives promoting productivity in science is more complex than generally believed and that the use of funding incentives and competition must be carefully pondered. At the same time, in such a context universities themselves have an incentive to allow their staff to undertake applied research and consultancies, thus opening up channels through which ease their budget constraints (Beath et al., 2003).

The new academic funding rationale and the promotion of external orientation of academic research have raised several theoretical and policy questions about the future role of universities and their future funding options. There is a large stream of literature focusing on the assessment of the potential advantages and disadvantages that such a shift can imply on the way universities create and transfer knowledge. Some authors point to the potentially negative effects of this shift toward industry funding on academic activities (Geuna, 2001; Elzinga, 1985; Florida and Cohen, 1999). Strehl et al. (2007), in their extensive OECD report on university funding systems and their effect on higher education systems, evidence the negative effects of the implementation of new institutional strategies in universities that involve the search for alternative resources to government funding, increasing consulting and marketing activities. The OECD report presents numerous country case studies based on stakeholders interviews and it investigates how institutions react to contingencies. The authors highlight that university stakeholders perceive as negative effects deriving from cuts in university funding the neglect of basic $R \& D$, lower quality of research and less variety in teaching courses. Moreover, increased competition between universities results in cooperation problems. Other authors show that university-industry collaboration per se has little negative impact on academic activities (Thursby and Thursby, 2011) and that both universities and businesses may benefit from collaboration (Gulbrandsen and Smeby, 2005). In fact, as suggested by Perkmann and Walsh (2009) industry involvement with universities under certain conditions (i.e. their discipline is associated with the 'sciences of the artificial'; they are highly research-driven; and they have a portfolio of different types of relationships with industry) will benefit the production of scientific research.

\subsection{Do private and public funding to universities complement or substitute each other?}

Less captured and understood are the possible effects of a cut in government funding to universities on their capability of establishing collaborative forms of interaction with firms, in particular those through which knowledge can be transferred to industry (as in the case of highly relational forms of collaborations such as research contracts and consultancies in their various forms), as well as on the options available for raising external funding.

The existence of a form of complementarity between these public and external funding to universities would imply that universities need government funding to increase the incidence of highly relational collaboration channels with industry (Mansfield, 1995; Cohen et al., 1998; Perkmann and Walsh, 2008; Jensen et al., 2010; Dechenaux et al., 2011) as well as their external fundraising options.

From a theoretical point of view, the grounds for the existence of a relationship between public and private funding to research within universities can be found in the literature addressing the issue of complementarity between public and private R\&D, which mostly focuses, recalling the theoretical basis provided by Arrow (1962), on the impact of public R\&D contracts and grants upon private R\&D investment by manufacturing firms and industries (David and Hall, 2000; David et al., 2000).
The issue of the positive direct and indirect effects of public R\&D on firms' productivity and private R\&D has been analysed thoroughly over the past 50 years. However, it is only the more recent literature that provides some theoretical and empirical insights on the nature and the characteristics of the relationship between public and private research, addressing the questions of (1) whether public and private $R \& D$ investments are linked and (2) under what conditions they behave like substitutes or complements. David and Hall (2000) contribute to this debate by analysing possible complementarities of public and private funding of R\&D conducted by firms. Through a simplified twosector model, the authors find that complementarity effects tend to be dominant when "the government RED sector is relatively high, the labour supply of scientists and engineers is elastic, or the marginal product RED curve is relatively flat (that is, the effect of RED on productivity does not fall very quickly as RED budgets increase)" (David and Hall, 2000, p. 1180). David et al. (2000) emphasise that complementarities between public and private R\&D investments can (a) derive from learning and training effects of publicly subsidised R\&D activities that acquaint enterprises with the latest advances in scientific knowledge, thus increasing their efficiency in their own R\&D programs; (b) emerge whenever public funding is made available for the construction of test facilities, for the acquisition of durable research equipment and for the bearing of the fixed costs of assembling specialised research teams, since all these circumstances lower the incremental costs of firms' R\&D projects; (c) be in place every time government contract R\&D signal future public sector product demand, because of a coordination effect which may raise the expected marginal rates of return on innovations targeted to the signalled market.

Within such a context, the publicly funded research carried out in universities makes no exception, as long as the advances in the knowledge base and the building of (technical and human capital) facilities it allows, can stimulate and complement industrial innovation. As a consequence, a link between public and private research funding to universities can be expected whenever firms, in order to develop their innovations, must rely on the material infrastructure the university has built and/or the expertise researchers have accumulated thanks to public research funding.

As for the nature of the relationship between public and private funding to universities, government and industry funding for research within universities can be strategic substitutes or complements. The scant literature specifically addressing this issue focuses on consultancies as the reference form of university industry interaction. Jensen et al. (2010) centre their analysis on the modelling of the actual mechanisms underlying the spillovers from academic research to industry, with a specific focus on research-driven consulting activities. They show that, under certain sufficient conditions, government and industry funding for university research act as strategic complements every time "an increase in either type of funding increases the marginal effect of the other on the probability that the researcher's university project will be successful" (p. 3), independently from the faculty reputation or quality. In their model, consultancies are the only source of spillovers, while signalling plays no role.

Other papers rely instead on signalling and reputation effects to explain complementarities. Connolly (1997) hypothesises that external sponsors wish to allocate funding to those universities that do the highest quality research, and that funding from either source provides information about quality. Similarly, Blume-Kohout et al. (2009) maintain that federal funding may serve as a signal of university quality, due to the extensive peer review conducted by the $\mathrm{NIH}$ and other federal agencies. 
To summarise the theoretical literature predicts the existence of complementarities when: knowledge spillover effects are present; firms have the possibility to free ride on university's already built equipment and staff (e.g. in research-driven and opportunity-driven consulting); firms are in need to capture uncodified knowledge when valuable expertise tends to be tacit and complex (e.g. in commercialisation-driven consulting); government funding work as a signalling and reputation mechanism. On the contrary, substitutability may emerge when spillover effects are absent or in peculiar situations related to the academics' work supply function (operating bounded time constraints or backward bending supply).

As a consequence, understanding the final effects of government funding on universities and, eventually, whether it substitutes or complements external funding from research contracts and consulting activity, is mainly an empirical question. The obvious policy implications of the substitution effect would be that government could reduce public funding to universities and cut public spending without hampering universities' financial sustainability, collaborations with industry and knowledge transfer, while the complementarity effect would imply that public funding would be indispensable, not only to guarantee the survival and the financial sustainability of universities, but also to consolidate universities' role as an engine of economic growth.

The relevance of this issue for the public opinion was already stressed by Diamond who argued that: "proposed cutbacks in government science funding have caused many to expect that the rate of scientific progress will significantly decline. Before the magnitude of the decline can be estimated, a preliminary question must be answered: "what is the extent to which private funding of science may be expected to fill the gap left by the declining government funding?" (Diamond, 1999, p. 423). In the same line of thinking, in the case of the US it has been observed that: "A priori, there could be a negative (substitution) effect, either due to crowding out of private investment or because researchers could stop seeking other sources of funding once they receive federal funding. On the other hand, federal R\&D funding could also have a positive impact due to complementarity or signalling effects" (Blume-Kohout et al., 2009, p. 30).

Moreover, according to Geuna and Nesta (2006) the reduction in structural (government) funds would produce great financial difficulties for most universities while benefiting only a few. For most universities revenues from research contracts and consultancies could be insufficient to compensate the decrease in structural funds and thus being detrimental to basic research activity and teaching. Considering that research contracts and consultancies are mainly demanded by organizations located in the proximity of universities (Capellari, 2011), this problem is exacerbated in the case of smaller universities located in less industrialised regions.

In line with the theoretical and empirical arguments raised in the related literature, we argue that government funding complement external funding and then contributes to stimulate universities' research activities whose results can be eventually transferred to industry. ${ }^{5}$ We argue that lack of government support to academic institutions may hamper universities' capability of attracting external funding, with possible negative consequences on knowledge transfer activities.

\footnotetext{
5 In support of this, Bozeman and Gaughan (2007) provide evidence that academic researchers who have research grants and contracts work more extensively with industry than those without grants or contracts. Furthermore, scientists who have industry contracts interact with industry to a greater degree than those who are exclusively funded by governments.
}

Table 1

Sample composition filed by scientific area.

\begin{tabular}{llcr}
\hline Code & Scientific area & Frequency & Percent \\
\hline 1 MAT-INF & Mathematics \& Computer Science & 85 & 7.23 \\
2 FIS & Physics & 53 & 4.51 \\
3 CHIM & Chemistry & 81 & 6.89 \\
4 GEO & Geology & 36 & 3.06 \\
5 BIO & Biology & 120 & 10.21 \\
6 MED & Medicine & 422 & 35.91 \\
7 AGR-VET & Agriculture \& Veterinary & 121 & 10.30 \\
8 ICAR & Civil Engineering \& Architecture & 121 & 10.30 \\
9 ING IND-INF & Industrial Engineering & 136 & 11.57 \\
Total & & 1232 & 100.00 \\
\hline
\end{tabular}

Source: Authors' calculations on MIUR data.

Research hypothesis: government funding to universities complement funding from research contracts and consulting activity.

\section{Empirical analysis}

\subsection{Data description}

The empirical analysis is based on financial data from the whole population of university departments in Italy engaged in research in all nine Scientific Areas (SA) of the Engineering and Physical Sciences (EPS). ${ }^{6}$ The data were provided by the Italian Ministry of University and Research (MIUR). We obtained financial data for the whole period 2005-2009, for 1175 EPS departments ${ }^{7}$ from 59 public universities (4 of them are polytechnic universities) located in 48 municipalities. We considered in the analysis all departments for which financial data was available for at least three consecutive years over the period 2005-2009.

The database provides information on volume and sources of university funding, staff composition, presence at the institution of an office managing European patents. These data were matched to data on research ratings and geographical characteristics obtained from other sources (see Table 3 ).

Table 1 reports the distribution of departments across the nine EPS SA. Most of these departments are in the field of Medicine, which counts 422 units and represents $35.9 \%$ of the total population. Industrial engineering accounts for $11.6 \%$ and Biology, Agriculture \& Veterinary, Civil Engineering \& Architecture account for around $10 \%$ each. Over the four-year period considered there was a substantial increase in research staff $(+14.7 \%)$ especially at a junior level (+19\% assistant professors).

\subsection{Recent changes in research funding in Italy}

Despite the rather slow emergence of initiatives to support knowledge transfer in Italy (Muscio and Orsenigo, 2010), the political pressure to commercialise the results of academic research has increased, ${ }^{8}$ prompting several universities to develop plans to support the commercial exploitation of scientific research. By 2000-2005 the majority of Italian universities had Technology Transfer Offices (TTO), some of which had been established for several years.

\footnotetext{
${ }^{6}$ The National University Council (CUN) classification of scientific areas is similar to that applied by the OECD in its Frascati Manual (OECD, 2002). The scientific areas considered here correspond to the areas identified by the Frascati Manual as: 1 . Natural Sciences, 2. Engineering \& Technology, 3. Medical Sciences, 4. Agricultural Sciences.

7 The list of the Italian departments is available at: www.cineca.it.

8 E.g., National laws D.L. 27/7/1999 no. 297 and D.M. 8/8/2000 no. 593 encourage and regulate the creation of university TTO. Art. 65 of the Codice dei Diritti di Proprietà Industriale, 10/02/2005, grants intellectual property rights to scientists for their scientific discoveries.
} 
Table 2

Department funding, 2006-2009 (Euros, mean values).

\begin{tabular}{|c|c|c|c|c|c|}
\hline Source of revenues & 2009 & $2009(\%)$ & $2006(\%)$ & $\begin{array}{l}2006-2009 \\
(\text { var. \%) }\end{array}$ & $\begin{array}{l}\text { 2006-2009 per } \\
\text { capita (var. \%) }\end{array}$ \\
\hline MIUR & 102,714 & 10.46 & 20.21 & -43.24 & -46.65 \\
\hline European commission & 132,218 & 13.47 & 9.17 & 61.07 & 51.39 \\
\hline Public research institutions & 33,728 & 3.44 & 2.81 & 33.80 & 25.75 \\
\hline Other public bodies & 141,545 & 14.42 & 10.84 & 45.77 & 37.01 \\
\hline Enterprises & 38,725 & 3.95 & 4.71 & -8.17 & -13.69 \\
\hline Not-for-profit organisations & 42,680 & 4.35 & 3.64 & 31.01 & 23.13 \\
\hline Foreign research institutions & 6,655 & 0.68 & 0.68 & 9.98 & 3.37 \\
\hline $\begin{array}{l}\text { Foreign private organisations (enterprises and } \\
\text { not-for-profit organisations) }\end{array}$ & 12,579 & 1.28 & 0.67 & 109.41 & 96.81 \\
\hline Own university & 138,577 & 14.12 & 16.24 & -4.70 & -10.43 \\
\hline Other sources & 23,442 & 2.39 & 3.46 & -24.37 & -28.92 \\
\hline $\begin{array}{l}\text { Research contracts and consultancies from } \\
\text { public and private organisations }{ }^{b}\end{array}$ & 308,683 & 31.45 & 27.58 & 24.99 & 17.47 \\
\hline Total & 981,546 & 100.00 & 100.00 & 9.60 & 3.01 \\
\hline
\end{tabular}

Source: Authors' calculations on MIUR data.

Notes:

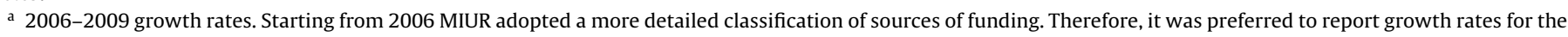
period 2006-2009.

b Research contracts and consultancies for public and private organisations are defined by the National Law 382/1980.

The financial data reported in Table 2 confirm a substantial cut in research funding in the period 2006-09. If in 2006 the primary source of funding for university departments was provided by MIUR which represented more than $20 \%$ of the entire research budget, in 2009 the primary sources of funding were research contracts and consultancies (31.45\%), funding from public bodies other than MIUR (e.g. regional and local administrations) (14.42\%), transfers from the university (14.12\%) and finally competitive research funding from MIUR (10.46\%). Over the period considered, research funding from MIUR was reduced by a substantial $43.24 \%$ whilst revenues from the majority of other sources increased. This reduced funding from MIUR has been offset by an increase in the transfers from other public bodies such as regional and local government institutions.

Arguably, this shift towards regional funding has been partially caused by the reform of the Constitutional Law introduced in 2001 that, with the introduction of the principle of subsidiarity (established in EU law by the 1992 Treaty of Maastricht), decreed the formal legislative autonomy of regions in several policy areas, including industrial policy, innovation and scientific research (e.g. before 2002 regions were not free to create their own regional agencies for innovation, laboratories or research networks, or develop their own innovation strategies). However, this increase in regional political autonomy has not yet been supported with a substantial increase in financial resources and expenditure capacity (Muscio and Orsenigo, 2010).

EC funding via competitive programmes such as the Framework Programmes, also increased by $61.07 \%$ over the period considered. The reduction in MIUR funding is even more striking if considered in terms of thousands of Euros per capita: total revenues remained basically stable (+3.01\%), whilst MIUR funding shrank by $46.65 \%$ though this was offset by increases in all other areas. Similar trends are common to other national public research bodies such as, for example, the National Research Council (CNR) (Coccia and Rolfo, 2008). ${ }^{9}$

\footnotetext{
9 The CNR is a major public research body similar in mission to the French Centre National de la Recerche Scientifique or to the German Max-Planck Gesellschaft. As part of two reforms introduced in 1999 and 2003 CNR budget was substantially reduced with two main consequences: public funds are not sufficient to cover current expenses and since 2001 staff recruitment has been stopped.
}

MIUR categorises private funding to departments as revenues from enterprises and revenues from research contracts and consultancies. Since 2006, funding from enterprises shrank by $8.17 \%$ and revenue from contracts increased by $27.58 \%$. This is confirmed empirically by Muscio (2010) who provides evidence of a relevant increase of frequency of university-industry research collaborations in recent years.

\subsection{Econometric specification}

Table 3 presents information on the variables used in the analysis. The dependent variable is the amount of funding raised by university departments as a result of research to order (contracts and consultancies) commissioned by public and private organisations and subject to university regulations. Following Perkmann and Walsh (2008), research can be distinguished in: research-driven consulting (contract research commissioned by firms); opportunity-driven and commercialisation-driven consulting (research or advisory services provided by individual academic researchers to industry clients). The dependent variable F_PRIVATE does not include business funding to departments that is not compensated by research results in return (such as in the case of private contribution for conferences and events, scholarships and prizes for proficient young researchers, etc.). These resources are in fact accounted as a separate source of revenue (see Table 2, under "Enterprises"), which in general is relatively small. Moreover, F_PRIVATE does not account for funding from research programmes/contracts that do not allow income distribution to research staff.

The explanatory variables are indicators of sources of revenue, department and university characteristics and regional economic indicators as proxies for external demand of university knowledge. Finally, we include yearly dummy variables to control for fixed temporal effects. Table 4 reports some descriptive statistics for the variables included in the regressions.

As a large part of the departments have no private funding, our dependent variable is partly continuous with a positive and large probability mass at zero. Hence, we model such a response variable in order to account for the presence of a corner solution outcome. We also allow for persistence in the process of collecting private finance by introducing a 1-year lag of the dependent variable, in order to investigate whether an evidence of an accumulation 
Table 3

Variable used in the regressions.

\begin{tabular}{|c|c|c|}
\hline Variable & Definition & Data source \\
\hline \multicolumn{3}{|l|}{ Departments' source of revenue } \\
\hline F_PRIVATE & $\begin{array}{l}\text { Volume of funding from research contracts and consultancies from public and } \\
\text { private organisations raised in the last financial year (2006-2009) }\end{array}$ & MIUR \\
\hline F_PRIVATE_Y & F_PRIVATE (yes/no) & MIUR \\
\hline F_EC & Research funding from the EC (2005-2009) & MIUR \\
\hline F_MIUR & Research funding from MIUR (2005-2009) & MIUR \\
\hline F_UNI & Research funding from own university (2005-2009) & MIUR \\
\hline F_ADMIN & $\begin{array}{l}\text { Research funding from other national and regional governmental bodies } \\
\text { (2006-2009) }\end{array}$ & MIUR \\
\hline \multicolumn{3}{|l|}{ Departments' characteristics } \\
\hline P_TOT & $\begin{array}{l}\text { Number of administrative staff, research staff (full professors, associate } \\
\text { professors, assistant professors, research officers) and PhD students } \\
\text { (2005-2009) }\end{array}$ & MIUR \\
\hline P_RESEARCH_S & Share of research staff (2005-2009) & MIUR \\
\hline P_PHD_S & Share of PHD students (2005-2009) & MIUR \\
\hline RES_RATING & $\begin{array}{l}\text { Research rating published by MIUR in 2007, based on the evaluation of } \\
\text { research output carried out over the period 2001-2003. This composite } \\
\text { indicator takes into account peer review evaluations of research activity } \\
\text { carried out at academic institutions (patents, impact factor of journal articles, } \\
\text { etc.) }\end{array}$ & CIVR VTR (MIUR, 2007) \\
\hline Scientific areas & Predominant departmental scientific research area & MIUR-CINECA \\
\hline a1 & SA Mathematics \& Computer Science & \\
\hline $\mathrm{a} 2$ & SA Physics & \\
\hline a3 & SA Chemistry & \\
\hline $\mathrm{a} 4$ & SA Geology & \\
\hline a5 & SA Biology & \\
\hline a6 & SA Medicine & \\
\hline a7 & SA Agriculture \& Veterinary & \\
\hline a8 & SA Civil Engineering \& Architecture & \\
\hline a9 & SA Industrial Engineering & \\
\hline \multicolumn{3}{|l|}{ University characteristics } \\
\hline SIZE_UNI1-4 & $\begin{array}{l}\text { Size of the academic institution where the department is located. University } \\
\text { size is expressed in terms of number of students: } 1 \text { small }(<10,000) ; 2 \text { medium } \\
(10,000-15,000) ; 3 \text { large }(15,000-40,000) ; 4 \text { mega }(>40,000)\end{array}$ & MIUR (2007) \\
\hline EPO_MNGMT & $\begin{array}{l}\text { Presence at the university of an office managing European patents. Normally } \\
\text { this task is carried out by offices for valorisation of research results or by TTOs. } \\
\text { These offices have the mission of supporting research staff in commercialising } \\
\text { the results of scientific research establishing collaborations and mediating } \\
\text { between agents }\end{array}$ & MIUR \\
\hline POLYTECH & Location of the department in a polytechnic university (four in Italy) & University website \\
\hline \multicolumn{3}{|l|}{ Indicators of local demand for technology } \\
\hline GEO_S, GEO_C, GEO_NE, GEO_NW & $\begin{array}{l}\text { Geographical location of the department respectively in Southern, Central, } \\
\text { North-East and North-West Italy }\end{array}$ & \\
\hline LOCAL_SIZE_MNF & $\begin{array}{l}\text { Average size of manufacturing companies in the administrative province } \\
\text { where the department is located }\end{array}$ & ISTAT 2001 Census \\
\hline LOCAL_EPO & $\begin{array}{l}\text { Number of European patents granted to industrial researchers resident in the } \\
\text { administrative province where the department is located during the period } \\
2000-2006\end{array}$ & $\begin{array}{l}\text { PATSTAT database elaborated } \\
\text { by Centro KITES, Università } \\
\text { Bocconi }\end{array}$ \\
\hline
\end{tabular}

advantage emerges along the lines of the Matthew effect argument (Merton, 1968).

Denote by $y_{i t}$ department $i$ 's private funding collected at time $t$, the dynamic panel Tobit model with department unobserved effects is:

$y_{i t}^{*}=x_{i t}^{\prime} \beta+c_{i}+c_{t}+u_{i t}, \quad i=1, \ldots, N, \quad t=1, \ldots, T$

$y_{i t}=\max \left(0, y_{i t}^{*}\right)$

where $x_{i t}$ is a set of department specific characteristics including the amount of government funding (namely European Union, MIUR, other public bodies, and internal university transfers) received in previous years, $c_{i}$ are the (random) department-specific effects, $c_{t}$ are the year effects, $u_{i t}$ is the error term. The year effects are included to account for cyclical variation in private funding. ${ }^{10}$ In order to handle the initial condition problem in dynamic, non-linear unobserved effects model, we follow the methodology

10 See Tables 3 and 4 for a more detailed definition of the controls used in the model and some summary statistics. suggested by Wooldridge (2005). ${ }^{11}$ We also report the results for a probit model where the dependent variable is a binary variable that is equal to 1 if the department received any private funding in the reference year, and 0 otherwise.

In both the tobit and probit estimates the regressors related to government funding are lagged up to two years in order to capture the dynamic effects on private funding. The vector $x_{i t}$ contains, apart from public financial resources, a set of covariates that might be correlated to the department capabilities to collect private funding, such as department size (both in term of administrative and research staff), quality/reputation, management, location,

\footnotetext{
11 The approach suggested in Wooldridge (2005) can be easily implemented for the Tobit and Probit regressions through a straightforward estimation using standard econometric software. This methodology implies to use as additional regressors the longitudinally averaged explanatory variables for each department and the initial outcome values. The coefficients of longitudinally averaged explanatory variables are not reported in the Table of the results and are available from the authors upon request.
} 
Table 4

Descriptive statistics.

\begin{tabular}{|c|c|c|c|c|}
\hline Variable & Mean & Std. dev. & Min & Max \\
\hline F_PRIVATE_09 & 286.61 & 524.45 & 0.00 & 5608.00 \\
\hline F_PRIVATE_08 & 245.61 & 402.77 & 0.00 & 3707.00 \\
\hline F_PRIVATE_07 & 216.99 & 363.43 & 0.00 & 3660.00 \\
\hline F_PRIVATE_06 & 217.81 & 382.43 & 0.00 & 4743.00 \\
\hline F_PRIVATE_Y & 0.85 & 0.36 & 0.00 & 1.00 \\
\hline F_EC_09 & 122.77 & 460.48 & 0.00 & 8924.00 \\
\hline F_EC_08 & 81.54 & 243.28 & 0.00 & 3857.00 \\
\hline F_EC_07 & 111.32 & 398.49 & 0.00 & 7585.00 \\
\hline F_EC_06 & 74.64 & 219.90 & 0.00 & 4062.00 \\
\hline F_EC_05 & 78.19 & 287.74 & 0.00 & 5721.00 \\
\hline F_MIUR_09 & 95.37 & 180.58 & 0.00 & 1689.00 \\
\hline F_MIUR_08 & 113.75 & 216.57 & 0.00 & 2423.00 \\
\hline F_MIUR_07 & 137.96 & 228.64 & 0.00 & 3295.00 \\
\hline F_MIUR_06 & 163.91 & 310.04 & 0.00 & 4000.00 \\
\hline F_MIUR_05 & 159.63 & 269.74 & 0.00 & 3064.00 \\
\hline F_UNI_09 & 128.67 & 154.05 & 0.00 & 1781.00 \\
\hline F_UNI_08 & 126.20 & 178.37 & 0.00 & 2268.00 \\
\hline F_UNI_07 & 118.42 & 143.91 & 0.00 & 1214.00 \\
\hline F_UNI_06 & 130.83 & 203.97 & 0.00 & 1984.00 \\
\hline F_UNI_05 & 119.57 & 156.58 & 0.00 & 2020.00 \\
\hline F_ADMIN_09 & 131.43 & 350.50 & 0.00 & 6652.00 \\
\hline F_ADMIN_08 & 104.58 & 271.84 & 0.00 & 4365.00 \\
\hline F_ADMIN_07 & 90.72 & 198.35 & 0.00 & 2468.00 \\
\hline F_ADMIN_06 & 86.14 & 204.30 & 0.00 & 2316.00 \\
\hline P_TOT_09 & 84.49 & 60.16 & 4.00 & 552.00 \\
\hline P_TOT_08 & 83.34 & 58.33 & 0.00 & 507.00 \\
\hline P_TOT_07 & 81.68 & 58.01 & 0.00 & 532.00 \\
\hline P_TOT_06 & 82.14 & 59.77 & 1.00 & 544.00 \\
\hline P_RESEARCH_S_09 & 0.42 & 0.16 & 0.00 & 1.00 \\
\hline P_RESEARCH_S_08 & 0.42 & 0.16 & 0.00 & 1.00 \\
\hline P_RESEARCH_S_07 & 0.44 & 0.17 & 0.10 & 1.00 \\
\hline P_RESEARCH_S_06 & 0.43 & 0.16 & 0.08 & 1.00 \\
\hline P_PHD_S_09 & 0.23 & 0.18 & 0.00 & 0.95 \\
\hline P_PHD_S_08 & 0.24 & 0.17 & 0.00 & 0.97 \\
\hline P_PHD_S_07 & 0.24 & 0.17 & 0.00 & 0.79 \\
\hline P_PHD_S_06 & 0.23 & 0.18 & 0.00 & 0.75 \\
\hline RES_RATING & 0.79 & 0.08 & 0.20 & 1.00 \\
\hline a1 & 0.07 & 0.26 & 0.00 & 1.00 \\
\hline $\mathrm{a} 2$ & 0.05 & 0.21 & 0.00 & 1.00 \\
\hline a3 & 0.07 & 0.26 & 0.00 & 1.00 \\
\hline $\mathrm{a} 4$ & 0.03 & 0.17 & 0.00 & 1.00 \\
\hline a5 & 0.10 & 0.30 & 0.00 & 1.00 \\
\hline a6 & 0.36 & 0.48 & 0.00 & 1.00 \\
\hline a7 & 0.10 & 0.30 & 0.00 & 1.00 \\
\hline a8 & 0.10 & 0.30 & 0.00 & 1.00 \\
\hline a9 & 0.11 & 0.32 & 0.00 & 1.00 \\
\hline SIZE_UNI1 & 0.08 & 0.27 & 0.00 & 1.00 \\
\hline SIZE_UNI2 & 0.07 & 0.26 & 0.00 & 1.00 \\
\hline SIZE_UNI3 & 0.44 & 0.50 & 0.00 & 1.00 \\
\hline SIZE_UNI4 & 0.41 & 0.49 & 0.00 & 1.00 \\
\hline EPO_MNGMT & 0.86 & 0.35 & 0.00 & 1.00 \\
\hline POLYTECH & 0.06 & 0.24 & 0.00 & 1.00 \\
\hline GEO_S & 0.32 & 0.46 & 0.00 & 1.00 \\
\hline GEO_C & 0.28 & 0.45 & 0.00 & 1.00 \\
\hline GEO_NE & 0.20 & 0.40 & 0.00 & 1.00 \\
\hline GEO_NW & 0.20 & 0.41 & 0.00 & 1.00 \\
\hline LOCAL_SIZE_MNF & 7.45 & 2.36 & 3.11 & 11.78 \\
\hline LOCAL_EPO & 11.71 & 17.95 & 0.00 & 58.70 \\
\hline
\end{tabular}

research areas and university structural characteristics ${ }^{12}$ and external spillovers.

\section{Results}

Table 5 reports the estimation results for the tobit model. Column (1) refers to a linear model that ignores the presence of a corner solution. Column (2) reports the result for the pooled tobit model

12 The results obtained using university dummies to control for university effects rather than specific controls for university structural characteristics are not substantially different and are available from the authors upon request. that ignores for the presence of unobserved random effects, while column (3) focuses on the unobserved effects dynamic tobit model which is our preferred specification. The marginal effects at the mean values on both $E\left(y_{i t} \mid x_{i t}, c_{i}\right)$ and $E\left(y_{i t} \mid x_{i t}, c_{i}, y_{i t}>0\right)$ are reported in columns (4) and (5) respectively. Table 6 shows the results for the probit model.

As expected, there is some path dependency to accessing private funding. For both the tobit and probit regressions the coefficients of the lagged dependent variables are positive and highly significant. In other words, accessing private funding increases both the probability of further funding from business and its volume in the future, which is consistent with the existence of a Matthew effect-like (Merton, 1968) accumulation pattern. This result confirms the findings of Arvanitis et al. (2008) who prove that, in the case of Switzerland, institutes which have already collaborated with industry - as reflected by a high share of external funds in an institute's budget - are more likely to be involved into overall knowledge transfer activities.

Both EU funding (F_EC) and MIUR (F_MIUR) have a positive and significant impact on departmental capability to raise private funding in both the tobit and probit regressions. When the presence of random effects is taken into account (column 3), the overall effect of both EU and MIUR funding is slighter smaller in size but remain significant at the standard level. To quantify the estimated overall effect, for every euro of domestic public support (MIUR) the department receives around 0.025 euro of funding from private contracts and the implied elasticity is around 0.02 . The long run coefficient calculated keeping into account the high persistence of private funding is around 0.04 . The tobit regressions show that EU funding is more effective in enhancing private funding than other sources of domestic financing (for 1 euro increase in the EU funding, private funding increases of 0.04 , while the effect of 1 additional euro of MIUR funding is about 0.025 increase in private funding). These results could be explained considering that the ability of the department to secure research grants from the EU, which are generally allocated on a fiercely peer-reviewed competitive basis at an international level, is taken as a signal of its research capabilities and thus raises the chance to secure further private funding from external collaborations and consultancies. Moreover, as the EU research grants aim to promote partnerships between universities and the industry, they tend to fund research projects that, even if focused on basic research, later on will have a higher likelihood of generating positive spillovers for the industry. The estimated effect is not large but in line with the evidence found in previous empirical works (Jensen et al., 2010).

In terms of probability (Table 6), the decline in government research grants experienced by Italian departments in the last five years has reduced the probability of getting private funding of about 2.5 percentage points while the increase in EU funding availability has increased the probability of 3 percentage points.

Public funding from other national and regional governmental bodies (FADMIN) complements the amount of private resources collected by departments and the size of coefficient is in line with the previous form of private financing, but it has not significant effects on the probability of obtaining private funding.

Not surprisingly, the effect of university internal transfers to departments is not significantly different from zero (F_UNI). This is because internal transfers are aimed not at promoting research but they are mainly used to provide general purpose resources or anticipate funding already allocated to departments for the next year/s. ${ }^{13}$

\footnotetext{
13 Internal transfers of resources have no effect on a department's capability to attract funding from industry because apart from any budget formally assigned to research activities, in most cases this funding is designed to cover expenses such as purchase of hardware and software, and researchers' subsistence for attendance at
} 
Table 5

Panel data tobit regressions.

\begin{tabular}{|c|c|c|c|c|c|}
\hline \multirow[t]{3}{*}{ Dependent variable: F_PRIVATE $(t)$} & \multirow{3}{*}{$\begin{array}{l}\text { (1) } \\
\text { OLS } \\
\text { Coefficients }\end{array}$} & \multirow{3}{*}{$\begin{array}{l}(2) \\
\text { Pooled dynamic tobit } \\
\text { Coefficients }\end{array}$} & (3) & \multirow{2}{*}{$\begin{array}{l}(4) \\
\text { ynamic tobit }\end{array}$} & \multirow[t]{2}{*}{ (5) } \\
\hline & & & Unobserved effects dynamic tobit & & \\
\hline & & & Coefficients & Marginal effects ( 1 ) & Marginal effects (2) \\
\hline F_PRIVATE $(t-1)$ & $\begin{array}{l}0.841 \\
(0.041)^{* * *}\end{array}$ & $\begin{array}{l}0.860 \\
(0.014)^{* * *}\end{array}$ & $\begin{array}{l}0.661 \\
(0.038)^{* * *}\end{array}$ & $\begin{array}{l}0.386 \\
(0.023)^{* * *}\end{array}$ & $\begin{array}{l}0.530 \\
(0.031)^{* * *}\end{array}$ \\
\hline F_EC $(t-1)$ & $\begin{array}{l}0.031 \\
(0.025)\end{array}$ & $\begin{array}{l}0.036 \\
(0.019)^{*}\end{array}$ & $\begin{array}{l}0.032 \\
(0.019)^{*}\end{array}$ & $\begin{array}{l}0.019 \\
(0.011)^{*}\end{array}$ & $\begin{array}{l}0.026 \\
(0.0151)^{*}\end{array}$ \\
\hline F_EC $(t-2)$ & $\begin{array}{l}0.011 \\
(0.035)\end{array}$ & $\begin{array}{l}0.009 \\
(0.019)\end{array}$ & $\begin{array}{l}0.009 \\
(0.019)\end{array}$ & $\begin{array}{l}0.005 \\
(0.011)\end{array}$ & $\begin{array}{l}0.007 \\
(0.0149)\end{array}$ \\
\hline F_MIUR $(t-1)$ & $\begin{array}{l}-0.054 \\
(0.052)\end{array}$ & $\begin{array}{l}-0.047 \\
(0.022)^{* *}\end{array}$ & $\begin{array}{l}-0.054 \\
(0.022)^{* *}\end{array}$ & $\begin{array}{l}-0.031 \\
(0.013)^{* *}\end{array}$ & $\begin{array}{l}-0.043 \\
(0.0178)^{* *}\end{array}$ \\
\hline F_MIUR $(t-2)$ & $\begin{array}{l}0.088 \\
(0.043)^{* *}\end{array}$ & $\begin{array}{l}0.094 \\
(0.021)^{* * * *}\end{array}$ & $\begin{array}{l}0.084 \\
(0.021)^{* * * *}\end{array}$ & $\begin{array}{l}0.049 \\
(0.012)^{* * * *}\end{array}$ & $\begin{array}{l}0.067 \\
(0.0169)^{* *}\end{array}$ \\
\hline F_UNI $(t-1)$ & $\begin{array}{l}-0.035 \\
(0.040)\end{array}$ & $\begin{array}{l}-0.034 \\
(0.034)\end{array}$ & $\begin{array}{l}-0.019 \\
(0.034)\end{array}$ & $\begin{array}{l}-0.011 \\
(0.019)\end{array}$ & $\begin{array}{l}-0.015 \\
(0.027)\end{array}$ \\
\hline F_UNI $(t-2)$ & $\begin{array}{l}0.023 \\
(0.042)\end{array}$ & $\begin{array}{l}0.031 \\
(0.035)\end{array}$ & $\begin{array}{l}0.022 \\
(0.035)\end{array}$ & $\begin{array}{l}0.013 \\
(0.020)\end{array}$ & $\begin{array}{l}0.018 \\
(0.028)\end{array}$ \\
\hline F_ADMIN $(t-1)$ & $\begin{array}{l}0.021 \\
(0.027)\end{array}$ & $\begin{array}{l}0.036 \\
(0.021)^{*}\end{array}$ & $\begin{array}{l}0.037 \\
(0.022)^{*}\end{array}$ & $\begin{array}{l}0.022 \\
(0.013)^{*}\end{array}$ & $\begin{array}{l}0.030 \\
(0.017)^{*}\end{array}$ \\
\hline P_TOT $(t-1)$ & $\begin{array}{l}0.649 \\
(0.139)^{* * *}\end{array}$ & $\begin{array}{l}0.777 \\
(0.110)^{* * *}\end{array}$ & $\begin{array}{l}0.810 \\
(0.116)^{* * *}\end{array}$ & $\begin{array}{l}0.473 \\
(0.067)^{* * *}\end{array}$ & $\begin{array}{l}0.649 \\
(0.092)^{* * *}\end{array}$ \\
\hline P_RESEARCH_S $(t-1)$ & $\begin{array}{l}167.395 \\
(50.620)^{* * *}\end{array}$ & $\begin{array}{l}107.917 \\
(63.770)^{*}\end{array}$ & $\begin{array}{l}117.880 \\
(66.981)^{*}\end{array}$ & $\begin{array}{l}68.852 \\
(39.137)^{*}\end{array}$ & $\begin{array}{l}94.426 \\
(53.665)^{*}\end{array}$ \\
\hline P_PHD_S $(t-1)$ & $\begin{array}{l}-77.649 \\
(27.032)^{* * *}\end{array}$ & $\begin{array}{l}-68.221 \\
(32.874)^{* *}\end{array}$ & $\begin{array}{l}-73.651 \\
(34.328)^{* *}\end{array}$ & $\begin{array}{l}-43.018 \\
(20.056)^{* *}\end{array}$ & $\begin{array}{l}-58.996 \\
(27.501)^{* *}\end{array}$ \\
\hline RES_RATING & $\begin{array}{l}104.020 \\
(52.482)^{* *}\end{array}$ & $\begin{array}{l}138.453 \\
(78.827)^{*}\end{array}$ & $\begin{array}{l}169.893 \\
(83.533)^{* *}\end{array}$ & $\begin{array}{l}99.232 \\
(48.79)^{* *}\end{array}$ & $\begin{array}{l}136.089 \\
(66.908)^{* *}\end{array}$ \\
\hline $\mathrm{a} 2$ & $\begin{array}{l}-11.756 \\
(25.212)\end{array}$ & $\begin{array}{l}-24.148 \\
(28.967)\end{array}$ & $\begin{array}{l}-28.942 \\
(30.738)\end{array}$ & $\begin{array}{l}-16.475 \\
(17.042)\end{array}$ & $\begin{array}{l}-22.760 \\
(23.707)\end{array}$ \\
\hline a3 & $\begin{array}{l}4.040 \\
(17.658)\end{array}$ & $\begin{array}{l}42.586 \\
(25.249)^{*}\end{array}$ & $\begin{array}{l}47.368 \\
(26.823)^{*}\end{array}$ & $\begin{array}{l}28.773 \\
(16.913)^{*}\end{array}$ & $\begin{array}{l}38.940 \\
(22.577)^{*}\end{array}$ \\
\hline a4 & $\begin{array}{l}17.235 \\
(19.475)\end{array}$ & $\begin{array}{l}64.502 \\
(31.893)^{* *}\end{array}$ & $\begin{array}{l}63.010 \\
(33.879)^{*}\end{array}$ & $\begin{array}{l}38.940 \\
(22.081)^{*}\end{array}$ & $\begin{array}{l}52.359 \\
(29.084)^{*}\end{array}$ \\
\hline a5 & $\begin{array}{l}1.436 \\
(15.711)\end{array}$ & $\begin{array}{l}20.482 \\
(23.604)\end{array}$ & $\begin{array}{l}20.853 \\
(25.011)\end{array}$ & $\begin{array}{l}12.378 \\
(15.083)\end{array}$ & $\begin{array}{l}16.888 \\
(20.470)\end{array}$ \\
\hline a6 & $\begin{array}{l}26.475 \\
(15.568)^{*}\end{array}$ & $\begin{array}{l}44.288 \\
(20.727)^{* *}\end{array}$ & $\begin{array}{l}47.926 \\
(21.980)^{* *}\end{array}$ & $\begin{array}{l}28.388 \\
(13.199)^{* *}\end{array}$ & $\begin{array}{l}38.743 \\
(17.917)^{* *}\end{array}$ \\
\hline a7 & $\begin{array}{l}43.880 \\
(19.790)^{* *}\end{array}$ & $\begin{array}{l}90.986 \\
(25.736)^{* * *}\end{array}$ & $\begin{array}{l}94.503 \\
(27.313)^{* * *}\end{array}$ & $\begin{array}{l}59.265 \\
(18.290)^{* * *}\end{array}$ & $\begin{array}{l}79.181 \\
(23.769)^{* * *}\end{array}$ \\
\hline a8 & $\begin{array}{l}61.815 \\
(21.909)^{* * *}\end{array}$ & $\begin{array}{l}106.624 \\
(24.365)^{* * *}\end{array}$ & $\begin{array}{l}112.092 \\
(25.953)^{* * *}\end{array}$ & $\begin{array}{l}71.191 \\
(17.784)^{* * *}\end{array}$ & $\begin{array}{l}94.590 \\
(22.850)^{* * *}\end{array}$ \\
\hline a9 & $\begin{array}{l}129.443 \\
(25.331)^{* * *}\end{array}$ & $\begin{array}{l}171.912 \\
(23.641)^{* * *}\end{array}$ & $\begin{array}{l}181.519 \\
(25.400)^{* * *}\end{array}$ & $\begin{array}{l}120.337 \\
(18.763)^{* * *}\end{array}$ & $\begin{array}{l}156.572 \\
(23.103)^{* * *}\end{array}$ \\
\hline SIZE_UNI1 & $\begin{array}{l}28.232 \\
(22.517)\end{array}$ & $\begin{array}{l}33.359 \\
(22.088)\end{array}$ & $\begin{array}{l}38.068 \\
(23.446)\end{array}$ & $\begin{array}{l}22.932 \\
(14.566)\end{array}$ & $\begin{array}{l}31.129 \\
(19.549)\end{array}$ \\
\hline SIZE_UNI2 & $\begin{array}{l}-36.012 \\
(18.610)^{*}\end{array}$ & $\begin{array}{l}-67.505 \\
(21.558)^{* * *}\end{array}$ & $\begin{array}{l}-75.555 \\
(22.883)^{* * *}\end{array}$ & $\begin{array}{l}-41.372 \\
(11.706)^{* * *}\end{array}$ & $\begin{array}{l}-57.655 \\
(16.527)^{* * *}\end{array}$ \\
\hline SIZE_UNI3 & $\begin{array}{l}14.227 \\
(10.871)\end{array}$ & $\begin{array}{l}21.119 \\
(12.455)^{*}\end{array}$ & $\begin{array}{l}21.115 \\
(13.186)\end{array}$ & $\begin{array}{l}12.366 \\
(7.743)\end{array}$ & $\begin{array}{l}16.944 \\
(10.599)\end{array}$ \\
\hline EPO_MNGMT & $\begin{array}{l}-4.389 \\
(13.485)\end{array}$ & $\begin{array}{l}-18.560 \\
(15.894)\end{array}$ & $\begin{array}{l}-15.448 \\
(16.821)\end{array}$ & $\begin{array}{l}-9.121 \\
(10.039)\end{array}$ & $\begin{array}{l}-12.466 \\
\text { ()13.673 }\end{array}$ \\
\hline POLYTECH & $\begin{array}{l}112.338 \\
(31.834)^{* * *}\end{array}$ & $\begin{array}{l}105.578 \\
(25.081)^{* * *}\end{array}$ & $\begin{array}{l}115.490 \\
(26.551)^{* * *}\end{array}$ & $\begin{array}{l}74.185 \\
(18.611)^{*}\end{array}$ & $\begin{array}{l}98.112 \\
(23.675)^{* * *}\end{array}$ \\
\hline GEO_S & $\begin{array}{l}-13.722 \\
(24.294)\end{array}$ & $\begin{array}{l}-49.095 \\
(25.177)^{*}\end{array}$ & $\begin{array}{l}-42.682 \\
(26.714)\end{array}$ & $\begin{array}{l}-24.542 \\
(15.111)^{*}\end{array}$ & $\begin{array}{l}-33.802 \\
(20.899)^{*}\end{array}$ \\
\hline GEO_C & $\begin{array}{l}-23.638 \\
(18.262)\end{array}$ & $\begin{array}{l}-30.529 \\
(21.943)\end{array}$ & $\begin{array}{l}-29.242 \\
(23.286)\end{array}$ & $\begin{array}{l}-16.864 \\
(13.261)\end{array}$ & $\begin{array}{r}-23.211 \\
(18.309)\end{array}$ \\
\hline GEO_NE & $\begin{array}{l}8.135 \\
(17.258)\end{array}$ & $\begin{array}{l}-2.637 \\
(18.553)\end{array}$ & $\begin{array}{l}4.309 \\
(19.719)\end{array}$ & $\begin{array}{l}2.523 \\
(11.583)\end{array}$ & $\begin{array}{l}3.458 \\
(15.851)\end{array}$ \\
\hline LOCAL_SIZE_MNF & $\begin{array}{l}-6.109 \\
(4.013)\end{array}$ & $\begin{array}{l}-3.959 \\
(3.685)\end{array}$ & $\begin{array}{l}-4.790 \\
(3.893)\end{array}$ & $\begin{array}{l}-2.798 \\
(2.274)\end{array}$ & $\begin{array}{l}-3.837 \\
(3.119)\end{array}$ \\
\hline LOCAL_EPO & $\begin{array}{l}1.106 \\
(0.509)^{* *}\end{array}$ & $\begin{array}{l}0.887 \\
(0.497)^{*}\end{array}$ & $\begin{array}{l}1.067 \\
(0.528)^{* *}\end{array}$ & $\begin{array}{l}0.623 \\
(0.309)^{* *}\end{array}$ & $\begin{array}{l}0.855 \\
(0.423)^{* *}\end{array}$ \\
\hline Constant & $\begin{array}{l}-190.221 \\
(81.840)^{* *}\end{array}$ & $\begin{array}{l}-235.434 \\
(94.629)^{* *}\end{array}$ & $\begin{array}{l}-271.247 \\
(100.063)^{* * *}\end{array}$ & $\begin{array}{l}- \\
-\end{array}$ & $\begin{array}{l}- \\
-\end{array}$ \\
\hline Year dummies & Yes & Yes & Yes & - & - \\
\hline Observations & 3293 & 3293 & 3293 & - & - \\
\hline No. of groups & - & - & 1175 & - & - \\
\hline Log-likelihood & - & -19853.210 & -19832.810 & - & - \\
\hline $\begin{array}{l}\text { R-squared/pseudo R-squared } \\
\text { Ho: rho }=0 \mathrm{a}\end{array}$ & 0.710 & $\begin{array}{l}0.710 \\
\chi^{2}=5.96, p \text {-value }=0.007\end{array}$ & 0.710 & - & - \\
\hline
\end{tabular}

Standard errors in parentheses.

Marginal effects (1): $\delta E(y \mid \mathbf{x}, c) / \delta x j$.

marginal effects (2): $\delta E(y \mid \mathbf{x}, c, y>0) / \delta x j$.

${ }^{a}$ Likelihood-ratio test comparing the random effects model with the pooled (tobit) model.

* Significant at $10 \%$.

** Significant at $5 \%$

**** Significant at $1 \%$. 
Overall, the econometric results for financial variables suggest a clear evidence of spillovers from government supported university research to more industry oriented research and consulting.

As an additional check, Table 7 presents the results of a Probit model, where the dependent variable is time invariant and assumes value 1 if the department has obtained some private funding in at least one year and 0 otherwise. In this way, we test if there is any effect of public funding on the initial decision of a department to access to private funding at all. ${ }^{14}$ This may be the case, for example, of departments highly specialised in basic research, which is generally underfunded by private sources and are not involved in the consultant activity. For these departments, we expect no relationship (neither complementarily nor substitution) between private and public sources of financing. Accordingly, the results of the Probit regression in Table 7 show that the probability of accessing to private funding does not depend on the availability of public research funding once we control for the department scientific area and size.

Looking at department and university characteristics, both tobit and probit regressions show that structural characteristics have an impact on business funding to departments. Departments' capacity of rising resources from private sources largely depends on the type of research carried out inside the departments. Departments assigned to research areas a9 (Industrial Engineering) and a8 (Civil Engineering and Architecture) and to a less extent a7 (Agriculture and Veterinary) are more involved in consulting activity. ${ }^{15}$

Departments in medium sized universities are less likely to attract business funding. ${ }^{16}$ There are positive effects of critical mass in large academic institutions on business funding expressed in terms of university reputation, visibility and size of research teams. On the other hand, small academic institutions tend to have fewer, highly specialised departments that are arguably more efficient (less bureaucratic procedures, more direct contact with local businesses, higher motivation to achieve visibility) in attracting business funding.

Universities with more EPS departments, such as polytechnic universities, are likely to have more refined practices and better services for technological collaborations with industry, and this affects positively the volume of business funding at a department level. On the other hand, the existence in the university of an office to manage European patents (EPO_MNGMT) does not seem to have any impact on the probability of attracting private funding nor its

conferences and scientific meetings. The per capita amounts of these transfers are typically capped at well below the amount required to finance structured research activities that are likely to attract firms and promote collaboration.

14 In our sample, 57 departments report of having received no funding from external collaboration and consultant activity over the observed period. They account for $15 \%$ of the departments operating in the field of Mathematics and Computer Science, $13 \%$ in Physics, and 10\% in Biology.

15 As a robustness check, we extend the analysis by including in the sample the departments active in all scientific disciplines. The effect of public funding on private funding is still positive and significant though a bit less quantitatively relevant. This generalisation suggests that all the research fields benefit from a larger public contribution to research activity in terms of their capability of attracting private resources. However, such effect is stronger when the research is more "industryintensive". Results are available from the authors upon request.

16 In our sample, the research departments operating in medium sized Universities report an average amount of funds from external collaborations of around 6 thousands euro per researcher every year, which accounts for $22 \%$ of total funding received by the department. In departments operating in small and large Universities the amount of funding from external collaborations is more than 8 thousands euro representing the $24 \%$ and $29 \%$ respectively of the total resources. The departments in the medium size Universities are also less effective in collecting funds from EU research grants, while there are not substantial differences for the other sources of financing.
Table 6

Panel data probit regressions.

\begin{tabular}{|c|c|c|}
\hline \multirow[t]{2}{*}{ Dependent variable: F_PRIVATE_Y } & \multicolumn{2}{|c|}{ Unobserved effects dynamic probit } \\
\hline & Coefficients & Marginal effects \\
\hline F_PRIVATE $(t-1)$ & $\begin{array}{l}0.002 \\
(0.000)^{* * *}\end{array}$ & $\begin{array}{l}0.0001 \\
(0.000)^{* * *}\end{array}$ \\
\hline F_EC $(t-1)$ & $\begin{array}{l}0.001 \\
(0.000)^{*}\end{array}$ & $\begin{array}{l}3.3 \mathrm{E}-05 \\
(0.0000)^{*}\end{array}$ \\
\hline F_EC $(t-2)$ & $\begin{array}{l}0.000 \\
(0.000)\end{array}$ & $\begin{array}{l}3.32 \mathrm{E}-05 \\
(0.0000)\end{array}$ \\
\hline F_MIUR $(t-1)$ & $\begin{array}{l}-0.000 \\
(0.000)\end{array}$ & $\begin{array}{l}-2.64 \mathrm{E}-06 \\
(0.0000)\end{array}$ \\
\hline F_MIUR $(t-2)$ & $\begin{array}{l}0.001 \\
(0.000)^{* *}\end{array}$ & $\begin{array}{l}2.35 \mathrm{E}-05 \\
(0.0000)^{* *}\end{array}$ \\
\hline F_UNI $(t-1)$ & $\begin{array}{l}-0.000 \\
(0.000)\end{array}$ & $\begin{array}{l}-8.44 \mathrm{E}-08 \\
(0.0000)\end{array}$ \\
\hline F_UNI $(t-2)$ & $\begin{array}{l}0.000 \\
(0.000)\end{array}$ & $\begin{array}{l}1.31 \mathrm{E}-05 \\
(0.0000)\end{array}$ \\
\hline F_ADMIN $(t-1)$ & $\begin{array}{l}0.000 \\
(0.000)\end{array}$ & $\begin{array}{l}4.05 \mathrm{E}-08 \\
(0.0000)\end{array}$ \\
\hline P_TOT $(t-1)$ & $\begin{array}{l}0.007 \\
(0.002)^{* * *}\end{array}$ & $\begin{array}{l}0.0003 \\
(0.0000)^{* * *}\end{array}$ \\
\hline P_RESEARCH_S $(t-1)$ & $\begin{array}{l}-0.341 \\
(0.704)\end{array}$ & $\begin{array}{l}-0.0013 \\
(0.0261)\end{array}$ \\
\hline P_PHD_S $(t-1)$ & $\begin{array}{l}-0.262 \\
(0.355)\end{array}$ & $\begin{array}{l}-0.0098 \\
(0.0142)\end{array}$ \\
\hline RES_RATING & $\begin{array}{l}0.103 \\
(0.893)\end{array}$ & $\begin{array}{l}0.0039 \\
(0.0336)\end{array}$ \\
\hline $\mathrm{a} 2$ & $\begin{array}{l}-0.361 \\
(0.317)\end{array}$ & $\begin{array}{l}-0.0194 \\
(0.0233)\end{array}$ \\
\hline a3 & $\begin{array}{l}1.356 \\
(0.337)^{* * * *}\end{array}$ & $\begin{array}{l}0.0186 \\
(0.0052)^{* * *}\end{array}$ \\
\hline $\mathrm{a} 4$ & $\begin{array}{l}1.943 \\
(0.490)^{* * *}\end{array}$ & $\begin{array}{l}0.0173 \\
(0.0049)^{* * *}\end{array}$ \\
\hline a5 & $\begin{array}{l}0.765 \\
(0.274)^{* * *}\end{array}$ & $\begin{array}{l}0.0160 \\
(0.0048)^{* * *}\end{array}$ \\
\hline $\mathrm{a} 6$ & $\begin{array}{l}0.539 \\
(0.232)^{* *}\end{array}$ & $\begin{array}{l}0.0178 \\
(0.0079)^{* *}\end{array}$ \\
\hline a7 & $\begin{array}{l}1.480 \\
(0.321)^{* * *}\end{array}$ & $\begin{array}{l}0.0215 \\
(0.0058)^{* * *}\end{array}$ \\
\hline a8 & $\begin{array}{l}1.490 \\
(0.315)^{* * *}\end{array}$ & $\begin{array}{l}0.0216 \\
(0.0059)^{* * *}\end{array}$ \\
\hline a9 & $\begin{array}{l}1.657 \\
(0.350)^{* * *}\end{array}$ & $\begin{array}{l}0.0240 \\
(0.0062)^{* * *}\end{array}$ \\
\hline SIZE_UNI1 & $\begin{array}{l}0.183 \\
(0.296)\end{array}$ & $\begin{array}{l}0.0059 \\
(0.0081)\end{array}$ \\
\hline SIZE_UNI2 & $\begin{array}{l}-0.620 \\
(0.248)^{* *}\end{array}$ & $\begin{array}{l}-0.0419 \\
(0.0268)\end{array}$ \\
\hline SIZE_UNI3 & $\begin{array}{l}0.261 \\
(0.159)\end{array}$ & $\begin{array}{l}0.0096 \\
(0.0061)\end{array}$ \\
\hline EPO_MNGMT & $\begin{array}{l}-0.096 \\
(0.189)\end{array}$ & $\begin{array}{l}-0.0034 \\
(0.0062)\end{array}$ \\
\hline POLYTECH & $\begin{array}{l}0.066 \\
(0.368)\end{array}$ & $\begin{array}{l}0.0023 \\
(0.0122)\end{array}$ \\
\hline GEO_S & $\begin{array}{l}-1.250 \\
(0.364)^{* * * *}\end{array}$ & $\begin{array}{l}-0.0894 \\
(0.043)^{* *}\end{array}$ \\
\hline GEO_C & $\begin{array}{l}-0.351 \\
(0.323)\end{array}$ & $\begin{array}{l}-0.0159 \\
(0.0176)\end{array}$ \\
\hline GEO_NE & $\begin{array}{l}-0.288 \\
(0.277)\end{array}$ & $\begin{array}{l}-0.0132 \\
(0.0154)\end{array}$ \\
\hline LOCAL_SIZE_MNF & $\begin{array}{l}0.048 \\
(0.048)\end{array}$ & $\begin{array}{l}0.0018 \\
(0.0017)\end{array}$ \\
\hline LOCAL_EPO & $\begin{array}{l}-0.006 \\
(0.007)\end{array}$ & $\begin{array}{l}-0.0002 \\
(0.0002)\end{array}$ \\
\hline Constant & $\begin{array}{l}0.592 \\
(1.107)\end{array}$ & - \\
\hline Year dummies & Yes & - \\
\hline Observations & 3293 & \\
\hline No. of groups & 1175 & \\
\hline Log-likelihood & -997.751 & \\
\hline Pseudo R-squared & 0.090 & \\
\hline
\end{tabular}

Standard errors in parentheses.

* Significant at $10 \%$

** Significant at $5 \%$.

*** Significant at $1 \%$. 
Table 7

Probit regressions robustness check.

\begin{tabular}{|c|c|c|c|c|}
\hline & $\begin{array}{l}(1) \\
\text { Pooled probit }\end{array}$ & $\begin{array}{l}(2) \\
\text { Year = } 2007\end{array}$ & $\begin{array}{l}(3) \\
\text { Year = } 2008\end{array}$ & $\begin{array}{l}(4) \\
\text { Year = } 2009\end{array}$ \\
\hline F_EC $(t-1)$ & $\begin{array}{l}0.000 \\
(0.000)\end{array}$ & $\begin{array}{l}-0.000 \\
(0.001)\end{array}$ & $\begin{array}{l}0.001 \\
(0.001)\end{array}$ & $\begin{array}{l}-0.000 \\
(0.001)\end{array}$ \\
\hline F_EC $(t-2)$ & $\begin{array}{l}-0.000 \\
(0.000)\end{array}$ & $\begin{array}{l}-0.000 \\
(0.000)\end{array}$ & $\begin{array}{l}-0.001 \\
(0.001)\end{array}$ & $\begin{array}{l}-0.000 \\
(0.001)\end{array}$ \\
\hline F_MIUR $(t-1)$ & $\begin{array}{l}0.000 \\
(0.000)\end{array}$ & $\begin{array}{l}0.000 \\
(0.000)\end{array}$ & $\begin{array}{l}-0.000 \\
(0.001)\end{array}$ & $\begin{array}{l}-0.000 \\
(0.001)\end{array}$ \\
\hline F_MIUR $(t-2)$ & $\begin{array}{l}0.000 \\
(0.000)\end{array}$ & $\begin{array}{l}-0.001 \\
(0.000)^{* *}\end{array}$ & $\begin{array}{l}0.000 \\
(0.000)\end{array}$ & $\begin{array}{l}-0.000 \\
(0.001)\end{array}$ \\
\hline F_UNI $(t-1)$ & $\begin{array}{l}0.000 \\
(0.000)\end{array}$ & $\begin{array}{l}0.001 \\
(0.000)\end{array}$ & $\begin{array}{l}-0.000 \\
(0.001)\end{array}$ & $\begin{array}{l}0.002 \\
(0.001)^{*}\end{array}$ \\
\hline F_UNI $(t-2)$ & $\begin{array}{l}0.000 \\
(0.000)\end{array}$ & $\begin{array}{l}0.001 \\
(0.000)\end{array}$ & $\begin{array}{l}0.001 \\
(0.001)^{* *}\end{array}$ & $\begin{array}{l}-0.001 \\
(0.001)\end{array}$ \\
\hline F_ADMIN $(t-1)$ & $\begin{array}{l}0.000 \\
(0.000)\end{array}$ & $\begin{array}{l}0.001 \\
(0.001)\end{array}$ & $\begin{array}{l}0.000 \\
(0.000)\end{array}$ & $\begin{array}{l}-0.000 \\
(0.000)\end{array}$ \\
\hline P_TOT $(t-1)$ & $\begin{array}{l}0.000 \\
(0.000)^{* *}\end{array}$ & $\begin{array}{l}0.002 \\
(0.001)^{*}\end{array}$ & $\begin{array}{l}-0.000 \\
(0.001)\end{array}$ & $\begin{array}{l}0.002 \\
(0.002)\end{array}$ \\
\hline P_RESEARCH_S $(t-1)$ & $\begin{array}{l}-0.084 \\
(0.028)^{* * *}\end{array}$ & $\begin{array}{l}-0.407 \\
(0.530)\end{array}$ & $\begin{array}{l}-1.094 \\
(0.539)^{* *}\end{array}$ & $\begin{array}{l}-0.498 \\
(0.242)^{* *}\end{array}$ \\
\hline P_PHD_S $(t-1)$ & $\begin{array}{l}0.006 \\
(0.013)\end{array}$ & $\begin{array}{l}-0.062 \\
(0.257)\end{array}$ & $\begin{array}{l}0.083 \\
(0.262)\end{array}$ & $\begin{array}{l}0.014 \\
(0.301)\end{array}$ \\
\hline RES_RATING & $\begin{array}{l}0.092 \\
(0.030)^{* * *}\end{array}$ & $\begin{array}{l}1.143 \\
(0.619)^{*}\end{array}$ & $\begin{array}{l}2.009 \\
(0.715)^{* * *}\end{array}$ & $\begin{array}{l}2.711 \\
(0.832)^{* * *}\end{array}$ \\
\hline a2 & $\begin{array}{l}-0.025 \\
(0.017)\end{array}$ & $\begin{array}{l}-0.242 \\
(0.196)\end{array}$ & $\begin{array}{l}-0.073 \\
(0.195)\end{array}$ & $\begin{array}{l}0.058 \\
(0.162)\end{array}$ \\
\hline a3 & $\begin{array}{l}0.022 \\
(0.004)^{* * *}\end{array}$ & $\begin{array}{l}0.099 \\
(0.187)\end{array}$ & $\begin{array}{l}0.159 \\
(0.202)\end{array}$ & $\begin{array}{l}0.348 \\
(0.046)^{* * *}\end{array}$ \\
\hline a5 & $\begin{array}{l}0.011 \\
(0.005)^{* *}\end{array}$ & $\begin{array}{c}-0.051 \\
(0.165)\end{array}$ & $\begin{array}{l}-0.084 \\
(0.181)\end{array}$ & $\begin{array}{l}0.198 \\
(0.128)\end{array}$ \\
\hline a6 & $\begin{array}{l}0.020 \\
(0.006)^{* * *}\end{array}$ & $\begin{array}{l}0.028 \\
(0.129)\end{array}$ & $\begin{array}{l}0.214 \\
(0.121)^{*}\end{array}$ & $\begin{array}{l}0.362 \\
(0.139)^{* * *}\end{array}$ \\
\hline a7 & $\begin{array}{l}0.029 \\
(0.004)^{* * *}\end{array}$ & $\begin{array}{l}0.251 \\
(0.102)^{* *}\end{array}$ & $\begin{array}{l}0.345 \\
(0.050)^{* * *}\end{array}$ & $\begin{array}{l}0.382 \\
(0.047)^{* * *}\end{array}$ \\
\hline a8 & $\begin{array}{l}0.028 \\
(0.004)^{* * *}\end{array}$ & $\begin{array}{l}0.165 \\
(0.138)\end{array}$ & $\begin{array}{l}0.292 \\
(0.061)^{* * *}\end{array}$ & $\begin{array}{l}0.356 \\
(0.055)^{* * *}\end{array}$ \\
\hline a9 & $\begin{array}{l}0.029 \\
(0.004)^{* * *}\end{array}$ & $\begin{array}{l}0.174 \\
(0.177)\end{array}$ & $\begin{array}{l}0.188 \\
(0.146)\end{array}$ & $\begin{array}{l}0.309 \\
(0.067)^{* * *}\end{array}$ \\
\hline SIZE_UNI1 & $\begin{array}{l}-0.009 \\
(0.014)\end{array}$ & $\begin{array}{l}0.170 \\
(0.151)\end{array}$ & $\begin{array}{l}-0.251 \\
(0.362)\end{array}$ & $\begin{array}{l}-0.045 \\
(0.224)\end{array}$ \\
\hline SIZE_UNI2 & $\begin{array}{l}-0.014 \\
(0.012)\end{array}$ & $\begin{array}{l}-0.206 \\
(0.202)\end{array}$ & $\begin{array}{l}-0.115 \\
(0.178)\end{array}$ & $\begin{array}{l}0.013 \\
(0.174)\end{array}$ \\
\hline SIZE_UNI3 & $\begin{array}{l}0.007 \\
(0.005)\end{array}$ & $\begin{array}{l}0.119 \\
(0.103)\end{array}$ & $\begin{array}{l}0.063 \\
(0.112)\end{array}$ & $\begin{array}{l}-0.032 \\
(0.114)\end{array}$ \\
\hline EPO_MNGMT & $\begin{array}{l}-0.007 \\
(0.005)\end{array}$ & $\begin{array}{l}-0.231 \\
(0.095)^{* *}\end{array}$ & $\begin{array}{l}-0.073 \\
(0.123)\end{array}$ & $\begin{array}{l}0.066 \\
(0.171)\end{array}$ \\
\hline POLYTECH & $\begin{array}{c}-0.014 \\
(0.019)\end{array}$ & $\begin{array}{l}-0.111 \\
(0.256)\end{array}$ & $\begin{array}{l}0.272 \\
(0.082)^{* * *}\end{array}$ & $\begin{array}{l}0.105 \\
(0.232)\end{array}$ \\
\hline GEO_S & $\begin{array}{l}-0.068 \\
(0.031)^{* *}\end{array}$ & $\begin{array}{l}-0.264 \\
(0.321)\end{array}$ & $\begin{array}{l}-0.444 \\
(0.278)\end{array}$ & $\begin{array}{l}-0.370 \\
(0.269)\end{array}$ \\
\hline GEO_C & $\begin{array}{l}-0.027 \\
(0.019)\end{array}$ & $\begin{array}{l}-0.193 \\
(0.321)\end{array}$ & $\begin{array}{l}-0.443 \\
(0.322)\end{array}$ & $\begin{array}{l}-0.337 \\
(0.288)\end{array}$ \\
\hline GEO_NE & $\begin{array}{l}-0.064 \\
(0.026)^{* *}\end{array}$ & $\begin{array}{l}-0.341 \\
(0.248)\end{array}$ & $\begin{array}{l}-0.542 \\
(0.204)^{* * *}\end{array}$ & $\begin{array}{l}-0.449 \\
(0.219)^{* *}\end{array}$ \\
\hline LOCAL_SIZE_MNF & $\begin{array}{l}0.003 \\
(0.002)\end{array}$ & $\begin{array}{c}-0.002 \\
(0.039)\end{array}$ & $\begin{array}{l}-0.055 \\
(0.041)\end{array}$ & $\begin{array}{l}-0.032 \\
(0.040)\end{array}$ \\
\hline LOCAL_EPO & $\begin{array}{l}-0.000 \\
(0.000)^{*}\end{array}$ & $\begin{array}{l}-0.006 \\
(0.006)\end{array}$ & $\begin{array}{l}-0.007 \\
(0.007)\end{array}$ & $\begin{array}{l}-0.004 \\
(0.007)\end{array}$ \\
\hline Observations & 3191 & 1051 & 1096 & 1044 \\
\hline Log-likelihood & -527.67 & -173.17 & -173.82 & -167.73 \\
\hline Pseudo R-squared & 0.209 & 0.218 & 0.222 & 0.242 \\
\hline
\end{tabular}

Standard errors in parentheses.

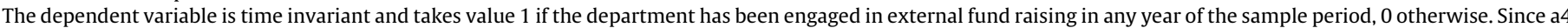

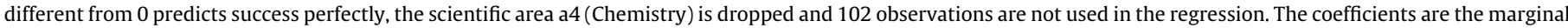
effects

* Significant at $10 \%$

** Significant at $5 \%$

Significant at $1 \%$.

volume. There has been a substantial increase in public and private investment in TTOs (Link and Scott, 2007) and there is a growing empirical literature on their contribution to the technology transfer process (Muscio, 2010).
The analysis of the impact of the department's geographical location on its capability to raise business funding provides mixed results. Both the tobit and probit regressions show that low levels of industrialisation, and poor infrastructure, e.g. the case 
of southern Italy (GEO_S), negatively affect a department's capability to establish collaboration with industry and raise private funding. Academic institutions in southern Italy are disadvantaged with respect to institutions located elsewhere in the country. Moreover, the proxy for local absorptive capacity for research services (LOCAL_EPO) is positive and significant. This result is in line with previous empirical findings. For example, Chapple et al. (2005) find that universities in regions with higher R\&D and gross domestic product (GDP) levels appear to be efficient in knowledge transfer activities, implying the existence of regional spillovers. Friedman and Silberman (2003) find that in regions with a concentration of high technology firms, more patent exploitation and co-patenting can be expected. Mansfield (1995) provides evidence that universities conducting higher quality research, and which are located close to innovating companies, make a greater contribution to industrial innovation. Firms tend to trade off faculty quality against geographic proximity, particularly in the case of applied R\&D.

There is also evidence that innovative firms favour research produced by high quality research universities and published in peer-reviewed journals (Bruno and Orsenigo, 2003; Pavitt, 2001; Hicks et al., 2000). In our analysis we use a research performance indicator to control first for whether high quality research generates valuable intellectual property that can be passed to industry and second for whether research performance provides a signal to industry of the best university departments. We find that research performance (RES_RATING) has a large and significant impact on business funding to universities, which means that both Matthew effects and signalling/reputation mechanisms are at work.

Instead, we have no information to allow us to test the impact of research quality on the frequency of interactions and the applicability of the research, on funding.

Bruno and Orsenigo's (2003) findings for the impact of department size on industry funding are confirmed. The number of staff (both administrative and research staff) has a positive and significant effect on both the volume of private funding collected by departments and on the probability of accessing private funding. Moreover, controlling for the number of people employed in the department, the capacity of collecting private research funding increases with the share of researchers involved in research activities, confirming that departments need to develop critical mass in research activities in order to attract businesses. Departments with larger numbers of research staff will benefit from greater visibility, greater specialisation of departmental research and more efficient procedures for the establishment and management of collaborations. Finally, the capability of attracting private funding is negatively related to the share of Ph.D. students to research stuff. This final measure reflects the facts that, ceteris paribus, Ph.D.s are obviously less effective than senior researchers in attracting private funding. Moreover, all else equal, the higher the PhD student/research ratio, the greater the advising roles of the more senior researchers and then less the time devoted to research (Jensen et al., 2010). ${ }^{17}$

\footnotetext{
17 We also tested the robustness of our results in several ways. We used an alternative proxy of research quality measured as the number of MIUR "PRIN" projects granted to departments obtaining similar results. We also tested for the presence of non-linearity in the effect of department size on private financing using a more flexible polynomial (second and third order) structure. The linearity assumption is not rejected by the data.
}

\section{Discussion and conclusions}

This paper investigates the relationship between different forms of public funding and private funding to university departments. We provide empirical evidence that public funding to universities complements private sources of funding provided via research contracts and consultancies. We find significant evidence of complementarities between public and private funding with an estimated private/public funding elasticity (both EU funding and domestic funding) of about 0.04 . We also confirm the results of previous studies providing evidence that the ability to produce good research is the pre-condition for the development of a strong role of universities towards industry (Bruno and Orsenigo, 2003).

We can formulate some concluding remarks and related policy implications to contribute to the on-going debate on the public/private funding of universities. This debate emerges from several recent statements in Europe and in the US, which underline the need for greater efforts by universities to increase private funding also through larger commercialisation of research activity. In the Italian case this is in line with the more pragmatic aim of a cut in government funding to universities, thus indirectly implying that public and private funding to universities are substitutes.

Our empirical analysis does not support the "substitution hypothesis". Public funding and funding from research contracts and consultancies are generally positively linked, meaning that these two forms of funding are strategically complementary. In other words, public funding can play an important role in stimulating those university-industry interactions. As a consequence, current initiatives aimed at cutting public funding to universities may negatively affect university-industry collaboration and their external fundraising capacity. Moreover, our analysis shows a high degree of persistence of private funding over time, implying that a reduction in public funding to universities would probably result in a further widening of the currently existing gap between those departments that are capable of attracting private funding and those that are not.

Finally, our results are likely to underestimate the extent of the complementarity between public and private sources as our data do not capture the actual volume of consulting activity (and therefore the impact of public funding on their sheer volume) as many direct engagements are not disclosed to university administrators.

In the specific case of Italy the decrease in competitive research funding from MIUR has been at least partially offset by an increase in funding from other public sources. This is partially due to the gradual implementation of the principle of subsidiarity. Interestingly, our results show that EU funding is more effective in enhancing private funding than other sources of domestic financing. This implies that, in order to foster university-industry interactions, the modalities through which public funds are granted and/or the projects to be funded are selected could play a crucial role.

Our empirical results can be extended to the countries that have not implemented (yet?) more advanced performance-based systems (see: Auranen and Nieminen, 2010; Strehl et al., 2007) in which the link between government funding to university and the interaction with industry is based on competitive criteria.

Finally, the dataset used in this paper imposes some limitations on the availability of measures and proxies of potentially relevant variables capturing researchers' incentives to collaborate with industry, such as ownership of intellectual property rights, revenues distribution to academic staff or the establishment of academic tariffs for tests and analyses. The impact of these factors on university-industry interactions is an interesting topic for future research. 


\section{Acknowledgements}

This work benefited from valuable inputs from Alessandra Colombelli, Aldo Geuna, Umberto Monarca, Fabio Montobbio, Luigi Orsenigo and two anonymous referees. The authors would like to thank the MIUR for the financial data on university departments, Centro KITES for the provision of patent data and Mariafebronia Sciacca for her help in building the database.

\section{References}

Arnold, E., Brown, N., Eriksson, A., Jansson, T., Muscio, A., Nählinder, J., Zaman, R., 2006. The Role of Industrial Research Institutes in The National Innovation System: A Report to Vinnova. Technopolis Group, Brighton (UK).

Arrow, K.J., 1962. Economic welfare and the allocation of resources to invention. In: Nelson, R. (Ed.), The Rate and Direction of Inventive Activity. Princeton Univ. Press, pp. 609-625.

Arvanitis, S., Kubli, U., Woerter, M., 2008. University-industry knowledge and technology transfer in Switzerland: what university scientists think about co-operation with private enterprises. Research Policy 37, 18651883.

Auranen, O., Nieminen, M., 2010. University research funding and publication performance-an international comparison. Research Policy 39 (6), 822-834.

Beath, J., Owen, R.F., Poyago-theotoky, J., 2003. Optimal incentives for incomegeneration in universities: the rule of thumb for the Compton tax. International Journal of Industrial Organization 21, 1301-1322.

Blume-Kohout, M.E., Kumar, K., Sood, N., 2009. Federal life sciences funding and university R\&D. NBER Working Paper Series 15146 (downloaded on 23 March 2012 from http://www.nber.org/papers/w15146.pdf?new_window=1).

Bozeman, B., Gaughan, M., 2007. Impacts of grants and contracts on academic researchers' interactions with industry. Research Policy 36, 694707.

Bruno, G.S.F., Orsenigo, L., 2003. Variables influencing industrial funding of academic research in Italy: an empirical analysis. International Journal of Technology Management 26 (2-3-4), 277-302.

Capellari, S., 2011. Università, mercato e imprese: una rassegna critica della letteratura recente, DEAMS Working Paper 1 (downloaded on 23 March 2012 from http://www.openstarts.units.it/dspace/bitstream/10077/4795/1/DEAMS _ Capellari_Universita_mercato_imprese.pdf).

Chapple, W., Lockett, A., Siegel, D., Wright, M., 2005. Assessing the relative performance of U.K. university technology transfer offices: parametric and nonparametric evidence. Research Policy 34, 369-384.

Cohen, W.M., Florida, R., Randazzese, L., Walsh, J., 1998. Industry and the academy: uneasy partners in the cause of technological advance. In: Noll, R.G. (Ed.), Challenges to Research Universities. The Brookings Institution, Washington D.C., pp. $171-200$.

Coccia, M., Rolfo, S., 2008. Strategic change of public research units in their scientific activity. Technovation 28 (8), 485-494.

Connolly, L.S., 1997. Does external funding of academic research crowd out institutional support? Journal of Public Economics 64 (3), 389-406.

David, P.A., Hall, B.H., 2000. Heart of darkness: modeling public-private funding interactions inside the R\&D black box. Research Policy 29 (9), 1165-1183.

David, P.A., Hall, B.H., Toole, A.A., 2000. Is public R\&D a complement or substitute for private R\&D? A review of the econometric evidence. Research Policy 29 (4-5), 497-529.

Dechenaux, E., Thursby, J., Thursby, M., 2011. Inventor moral hazard in university licensing: the role of contracts. Research Policy 40 (1), 94-104.

Diamond, A., 1999. Does federal funding crowd in private funding of science? Contemporary Economic Policy 17 (4), 423-431.

Drucker, P., 1993. Post-capitalist Society. HarperBusiness, New York.

Edvinsson, L., Malone, M.S., 1997. Intellectual Capital: Realizing your Company's True Value by Finding it's Hidden Roots. HarperCollins Publishers Inc., New York.

Elzinga, A., 1985. Research, bureaucracy and the drift of epistemic criteria. In: Wittrock, B., Elzinga, A. (Eds.), The University Research System. Almqvist \& Wiksell, Stockholm.

European Commission, 2009. Diversified funding streams for universitybased research: impact of external project-based research funding on financial management in universities. Directorate-General for Research, Expert Group report chaired by S. Herlitschka (downloaded on 23 March 2012 from http://ec.europa.eu/invest-in-research/ pdf/download_en/external_funding_final_report.pdf).

Florida, R., 1995. Toward the learning region. Futures 27 (5), 527-536.

Florida, R., Cohen, W., 1999. Engine or infrastructure? The university's role on economic development. In: Branscomb, L., Kodama, F., Florida, R. (Eds.), Industrializing Knowledge. MIT Press, pp. 589-610.

Friedman, J., Silberman, J., 2003. University technology transfer: do incentives, management, and location matter? Journal of Technology Transfer 28, 17-30.

Gandolfi, S., 2009. Italia, povera ricerca. Corriere della Sera, January 20 (downloaded on 23 March 2012 from http://www.corriere.it/cronache/09. gennaio_20/magazine_povera_ricerca_cover_story_86e615f8-e6f5-11dd8f4d-00144f02aabc.shtml).
Geuna, A., 1999. The Economics of Knowledge Production. Funding and the Structure of University Research. Edward Elgar, Cheltenham.

Geuna, A., 2001. The changing rationale for European university research funding: are there negative unintended consequences? Journal of Economic Issues 25 607-632.

Geuna, A., Muscio, A., 2009. The Governance of university knowledge transfer: a critical review of the literature. Minerva 47, 93-114.

Geuna, A., Nesta, L., 2006. University patenting and its effects on academic research: the emerging European evidence. Research Policy 35, 790-807.

Gulbrandsen, M., Smeby, J.C., 2005. Industry funding and university professors research performance. Research Policy 34, 932-950.

Gulbrandsen, M., Mowery, D., Feldman, M., 2011. Introduction to the special section: heterogeneity and university-industry relations. Research Policy 40 (1), 1-5.

Hicks, D., Breizman, A., Hamilton, K., Narin, F., 2000. Research excellence and patented innovation. Science and Public Policy 27, 310320.

Intravaia, S., 2011. Sempre meno soldi per la ricerca, giù del $7 \%$ le risorse degli atenei, La Repubblica, March 7 (downloaded on 23 March 2012 from http://www.repubblica.it/scuola/2011/03/07/news/tagli_ricerca13295022/index.html?ref=search).

Jensen, R., Thursby J., Thursby M.C., 2010. University-industry spillovers, government funding, and industrial consulting. NBER Working Paper, 15732.

Laredo, P., 2007. Toward a third mission for universities. Paper presented at the Regional Seminar Globalizing Knowledge: European and North American Regions and Policies Addressing the Priority Issues of Other UNESCO Regions. Paper presented at the UNESCO Forum on Higher Education, Research and Knowledge, Paris, 5-6 March 2007.

Leonard-Barton, D., 1995. Wellsprings of Knowledge: Building and Sustaining the Sources of Innovation. Harvard Business School Press, Boston.

Link, A.N., Scott, J.T., 2007. The economics of university research parks. Oxford Review of Economic Policy 23 (4), 620-639.

Magrini, M., 2011. Percheǐ l'Italia non cresce 11/La ricerca non trova merito. Il Sole 24 Ore, April 13 (downloaded on 23 March 2012 from http://www.ilsole24ore.com/art/commenti-e-idee/2011-04-13/ricercatrova-merito-063943.shtml?uuid=Aang1UOD\&fromSearch).

Mansfield, E., 1995. Academic research underlying industrial innovation: sources characteristics and financing. Review of Economics and Statistics 77, 55-65.

McNab, R.M., Melese, F., 2003. Implementing the GPRA: examining the prospects for performance budgeting in the federal government. Public Budgeting \& Finance 23 (2), 73-95.

Merton, R.K., 1968. The Matthew effect in science. Science 159, 56-63.

MIUR - Ministero dell'Università e della Ricerca, 2007. VTR 2001-2003: Relazione Finale. CIVR, Comitato per la Valutazione della Ricerca, Roma.

Muscio, A., 2010. What drives university access to technology transfer offices? Evidence from Italy. Journal of Technology Transfer 35 (2), 181202.

Muscio, A., Orsenigo, L., (2010). Politiche nazionali e regionali di diffusione della conoscenza. In: Bianchi, P., Pozzi, C. (Eds.), Le politiche industriali alla prova del futuro-analisi per una strategia nazionale, Il Mulino.

Nonaka, I., Takeuchi, H., 1995. The Knowledge-Creating Company: How Japanese Companies Create the Dynamics of Innovation. Oxford University Press, New York.

OECD, 2002. Frascati Manual: Proposed Standard Practice for Surveys on Research and Experimental Development. OECD Publishing.

OECD, 2010. Performance-based Funding for Public Research in Tertiary Education Institutions, Workshop Proceedings. OECD Publishing.

Pavitt, K., 2001. Public policies to support basic research: What can the rest of the world learn from US theory and practice? (and what they should not learn). Industrial and Corporate Change 10 (3), 761-780.

Perkmann, M., Walsh, K., 2008. Engaging the scholar: three forms of academic consulting and their impact on universities and industry. Research Policy 37 (10) 1884-1891.

Perkmann, M., Walsh, K., 2009. The two faces of collaboration: impacts of university-industry relations on public research. Industrial and Corporate Change 18 (6), 1033-1065.

Romer, P., 1993, Ideas and things, The Economist, Supplement, September 11.

Romer, P., 1995. Beyond the knowledge worker. World Link (January-February), 56-60.

Salmi, J., Hauptman, A.M., 2006. Resource allocation mechanisms in tertiary education: a typology and an assessment. In: Guni (Ed.), Higher Education in the World 2006: The Financing of Universities. Palgrave MacMillan, pp. 60-81.

Sörlin, S., 2007. Trends and Issues in the Funding of Research. Paper presented at the Regional Seminar Globalizing Knowledge: European and North American Regions and Policies Addressing the Priority Issues of other UNESCO Regions. Paper presented at the UNESCO Forum on Higher Education, Research and Knowledge, Paris, 5-6 March 2007.

Steil, B., Victor, D.G., Nelson, R.R. (Eds.), 2002. Technological Innovation and Economic Performance. Princeton University Press, Princeton, Oxford.

Stewart, T.A., 1997. Intellectual Capital: The New Wealth of Organizations. Doubleday, New York

Strehl, F., Reisinger, S., Kalatschan, M., 2007. Funding Systems and Their Effects on Higher Education Systems. OECD Education Working Papers 6.

Thursby, J., Thursby, M.C., 2011. Faculty participation in licensing: implications for research. Research Policy 40 (1), 20-29. 
Tucci, C., 2010, Tagliati 279 milioni alle università, Il Sole 24 Ore, September 15 (downloaded on 23 March 2012 from http://www.ilsole24ore.com/ art/notizie/2010-09-15/tagliati-milioni-universita-201410.shtml?uuid= AYZOtCQC\&fromSearch).

Van Looy, B., Ranga, M., Callaert, J., Debackere, K., Zimmermann, E., 2004. Combining entrepreneurial and scientific performance in academia: towards a compounded and reciprocal Matthew effect? Research Policy 33 (3), 425441.

Wooldridge, J.M., 2005. Simple solutions to the initial conditions problem in dynamic, nonlinear panel data models with unobserved heterogeneity. Journal of Applied Econometrics 20 (1), 39-54.

Please cite this article in press as: Muscio, A., et al., Does government funding complement or substitute private research funding to universities? 